\title{
Informationskompetencer og informationskompetenceudvikling
}

\author{
Af Claus Bjerg
}

\section{Indledning}

I kraft af ændringer i pædagogikken og undervisningen de sidste 15-20 år er informationssøgning og biblioteker blevet vigtige elementer i de studerendes studiearbejde, da almindelig undervisning suppleres af de studerendes studieaktivitet via projekter, st $\varnothing r r e$ studieopgaver og specialer. Uddannelsesbiblioteker er vigtige for undervisningen som tilgængelige materialecentre, og informationssøgning ses som en væsentlig proces i de studerendes selvstændige studiearbejde og læring. Et fælles mål for uddannelsesinstitutionerne er at udvikle de studerendes studiemetoder. Informationskompetenceudvikling er en integreret del af studiemetoderne, og erhvervede informationskompetencer gør de studerende i stand til at finde, udvælge, vurdere og anvende informationer fra de mest hensigtsmæssige kilder og faglige tekster i deres studiearbejde. Dette betyder, at de studerende gennem informationskompetenceudvikling erhverver sig mere målrettede måder at studere på, således de kan arbejde sig dybere ned i de forskellige fag. Informationskompetenceudvikling hos de studerende har til hensigt at forbedre de måder som de studerende lærer på. Den teknologiske udvikling har gjort informationskompetencer særdeles nødvendige, idet redskaber som fagbøger, databaser, internetdokumenter, elektroniske og fysiske tidsskrifter medierer læring på forskellig vis. IT-redskaber fungerer ikke kun som støtte til læring, men ændrer også selve den kognitive proces. Bibliotekerne skal således ikke kun øge de studerendes kendskab til forskellige informationssystemer og informationsressourcer, men skal også i brugerundervisningen og i den informationsfaglige vejledning sammen med lærerne være med til at udvikle studiemetoder i forbindelse med den enkeltes egne læreprocesser. Et vigtigt mål er at udvikle de studerendes kritiske opmærksomhed i forhold til information og viden i alle dele af uddannelsen og i undersøgelsesarbejdet i forbindelse med større opgaver og projekter - og ikke bare i forhold til selve informationssøgningsfasen. Udvikling af informationskompetencer betyder derved udvikling af de studerendes kritiske tænkning i deres studieforløb i form af en kritisk forholden sig til forskellige informationskilder og informationssystemer og re eksion over egen brug af forskellige informationssystemer. Eksempelvis opfatter mange studerende sig selv som suveræne internetbrugere, men min erfaring viser, at de ofte anvender internet- 
tet ret ukritisk og ure ekteret. For at nå disse mål er det efter min opfattelse nødvendigt, at lærere og bibliotekarer sammen udvikler undervisnings- og læringsforl $\emptyset \mathrm{b}$, hvor de studerende udfordres på deres kritiske tænkning i forbindelse med informationssøgning og i de processer, hvor information bearbejdes til ny viden for den enkelte.

I denne artikel præsenteres informationskompetencebegrebet i centrale forskeres forståelse. Jeg vil desuden præsentere et informationskompetenceudviklingsprojekt, hvor lærere og bibliotekarer i CVU -MidtVest (ㅌenter for Videregående $\underline{\text { Udddannelser }}$ - MidtVest) sætter fokus på udvikling af informationskompetencer, som en del af de studerendes udvikling af hensigtsmæssige studiemetoder (fra elev til studerende) og læreprocesser og ligeledes sættes fokus på samarbejdet mellem bibliotekarer og lærere og uddannelsesinstitutionernes ledelser om fælles forståelse af informationskompetenceudvikling. De 5 partnerinstitutioner i CVU - MidtVest: Skive Seminarium, Nr. Nissum Seminarium, Ikastseminariet, CVU - MidtVests Efter og videreuddannelsesafdeling og Viborg-seminariet udbyder lærerog pædagoguddannelser, Pædagogiske Diplomuddannelser (PD), Voksenunderviseruddannelsen og Friluftsvejlederuddannelsen, samt pædagogisk efteruddannelse.

\section{Kompetence og informationskompetence}

Kompetencebegrebet er i de senere år blevet centralt i samfundsmæssige og uddannelsesmæssige sammenhænge. Kompetenceudvikling ses som henholdsvis styrkelse af konkurrencefordele, medarbejderudvikling, national konkurrenceevne og social sammenhængskraft. Begrebet defineres ikke entydigt, men der er enighed om, at kompetencer skal forstås mere bredt end kvalifikationer. Kompetence kan opfattes som indre personlige dynamikker som sammen med viden og indsigter anvendes i konkrete situationer, hvor menneskelige udfordringer og problemer skal håndteres $\mathrm{og}$ antages at have stor betydning, og er en forudsætning for den enkelte for at kunne navigere i privatlivet og i det professionelle arbejdsliv. (Hermann, 2003, s.7) Der er enighed om, at kvalifikationer skal forstås som evnen til at udføre en på forhånd defineret arbejdsfunktion, mens kompetencebegrebet refererer til, at den enkelte kan analysere, træffe beslutninger og forholde sig kreativt i forhold til de situationer, man stilles overfor. (Pilegaard, 2002, s. 23). I uddannelse er kompetence tæt knyttet til metode. Kompetencetænkningen er dog ikke forankret i bestemte overordnede menneskelige og samfundsmæssige mål. Det er en svaghed, at kompetencer er forankret i sig selv. Kompetence til at søge informationer - uanset hvilke! Kompetencebegrebet skal således forstås som den helhed af kompetencer en medborger i større eller mindre grad må besidde for at kunne håndtere de udfordringer, som vedkommende møder i det private, samfunds-, uddannelses- og arbejdsmæssige liv. Danmark deltager med 11 andre lande i OECD projektet "Definition and Selection of Competencies" og er gennem "Det nationale kompetenceregnskab" i gang med at definere forskellige nøglekompetencer (Nøglekompetencer, 2002). Begrebet informationskompetence defineres i denne sammenhæng ikke eksplicit, men defineres gennem nøglekompetencerne læringskompetence og literacy. I literacy-begrebet er reading literacy centralt, idet opfattelsen her er, at den enkelte må være i stand til at forstå, anvende og re ektere over skrevne tekster.

"Alle job stiller i dag i større eller mindre ud-
strækning krav om evnen til at uddrage brugbar
information af skriftligt materiale som en ba-
sisforudsætning for at kunne bestride et job. I
dette indgår, at den enkelte også evner at sortere,
vurdere den givne information med henblik på at
tage beslutninger, som viser sig at være rigtige,
dvs. føre til målet for aktiviteten." (Pilegaard, 2002, s. 24)

Informationskompetencebegrebet er således et bredere begreb end begrebet "reading literacy" og det inddrager også evnen til at indhente relevant information fra de forskellige informationssystemer også via beherskelse af relevante IT-kompetencer. Informationskompetence er efter min opfattelse et mere 
fyldestgørende begreb, hvor der vægtes beherskelse af de processer og værkt $\varnothing j e r$, der er nødvendige for at indhente relevant information, beherskelse af indhold og forståelse på emneområdet og forståelse for de sammenhænge som teksterne indgår i (kildekritiske kompetencer). I OECDs PISA (Programme for International Student Assessment ) undersøgelse, som den fremstilles af Torben Pilegaard Jensen (Pilegaard 2002, s. 28) er der stor overensstemmelse med reading literacy og information literacy, hvor det at finde og indhente information dog ikke ser ud til at vægtes så meget.

Det er vigtigt for studerende i deres uddannelse på alle niveauer at udvikle studiekompetencer, herunder blandt andet at udvikle informationskompetencer for at kunne "forholde" sig til at finde, anskaffe, vurdere, og anvende information til opbygning af ny viden i forbindelse med studiearbejdet. Et vigtigt mål er at lære at lære og at tage ansvar for egen læring - hvilket indbefatter informationskompetencer på et vist niveau. Udvikling af informationskompetencer på et tilfredsstillende niveau er eksempelvis en forudsætning for at være i stand til at udarbejde et niveausvarende bachelor-speciale på mellemlange videregående uddannelser. I Undervisningsministeriets kriterier om bacheloruddannelser, som er kvalitative krav til uddannelsesinstitutionerne på de mellemlange videregående uddannelser hedder det blandt andet:

"De relevante informationskilder, herunder IT og biblioteksfaciliteter, er tilgængelige og på et tilfredsstillende niveau i forhold til uddannelsens målsætning. De studerende gives mulighed for at opnå forudsætninger for anvendelse af informationskilder".

(Undervisningsministeriet, 2002, pkt 4.2.2)

Endvidere formuleres det i bekendtgørelsen om pædagoguddannelsen om de afsluttende bachelorspecialer i pædagoguddannelsen, at de studerende skal opnå :

1. Særlig indsigt $\mathrm{i}$ et afgrænset centralt område eller problem af både teoretisk og praktisk karakter indenfor det pædagogiske felt.

2. Færdighed $i$ at indsamle, bearbejde og anvende relevant information

3. Færdighed $i$ at formidle egne fagligt begrundede opfattelser

(Bek. nr. 706 af 23/7 2001 om pædagoguddannelsen $\S 6$, stk 2)

\section{Informationskompetencebegrebets udvikling}

Historisk har informationskompetencetænkningen udviklet sig parallelt med IT-udviklingen og især i forbindelse med de informationsressourcer, som bl.a. via WWW er gjort tilgængelige for mange studerende og elever.

Disse intellektuelle evner til selvstændigt at finde, fremskaffe, vurdere, og anvende information kaldes under et for "Information Literacy" - andre kalder det af formidlingsmæssige årsager "information competence". Det er et begreb, som er udviklet i USA omkring 1974, og som siden er videreudviklet i utallige sammenhænge og på tværs af faggrænser. Begrebet er blevet brugt og anvendt i studieordninger på uddannelsesinstitutioner overalt i USA siden 1992 (Bawden, 2001; Breivik, 1998, s.11; Spitzer, 1998, s. 22-32). I 1989 dannedes i USA "National Forum on Information Literacy" med deltagelse af 50 landsdækkende organisationer. Adskillige initiativer er udgået herfra, og især formulering af informationskompetencestandarder i form af målsætninger for de studerendes informationskompetence har haft en vis gennemslagskraft på mange uddannelsesinstitutioner i USA. Samme udvikling er set i Australien, England og Sydafrika og foregår i øjeblikket også i nordisk regi, hvor NORDINFO søger at arbejde for nordiske informationskompetencestandarder. I øjeblikket afholdes mange steder i Norden konferencer, kurser og møder med informationskompetenceudvikling som fokuspunkt.

Da information er indeholdt i mange formater og former, skal informationskompetence forstås som mere end det at den enkelte kan anvende litteratur 
og biblioteksbaser, men tillige at den enkelte har en kritisk tilgang til og kan anvende såvel trykte og elektroniske tekster, web-udgivelser, billeder, lyd, computersoftware og netværk. Det er meget vigtigt at opfatte informationskompetence som mere end det at opnå IT-færdigheder gennem erhvervelse af forskellige former for IT-kørekort. Der er adskillige fors $\emptyset \mathrm{g}$ på at definere informationskompetence. Louise Limberg nævner i forskningsoversigten Informationssökning och lärande (Limberg et al., 2002) American Library Association's (ALA) Presidential Committe's definition som den vigtigste og oftest citerede.

»To be information literate, a person must be able to recognize when information is needed and have the ability to locate, evaluate and use effectively the information needed. Ultimately information literate people are those who have learned how to learn. They know how to learn because they know how information is organized, how to find information, and how to use information in such a way that others can learn from them"

(American Library Association. 1989, s.1)

Christine Bruce definerer i sin ph.d.-afhandling et alsidigt informationskompetencebegreb, som forstås som den enkeltes sammensatte måde at erfare omverdenen på: at forstå information, forståelse for kritisk, kreativt brug af information, at kunne generere viden af information, at forstå at anvende informationssystemer herunder biblioteker, IT-værktøjer, databaser, internet og forståelse for informationssøgningsprocessers og videngenereringens kompleksitet (Bruce, 1997, s.119-151).

Jeg vil i det følgende præsentere tre væsentlige opfattelser af begrebet informationskompetence fra Christine Bruce, Christina Doyle og Elisabeth Dupuis, som har været vigtige for min opfattelse af informationskompetencer og informationskompetenceudvikling.

\section{Forståelser af informationskompetence}

Informationskompetencebegrebet er blevet behandlet teoretisk i mange forskellige sammenhænge og af mange forskellige forskere, og der er tale om mange videnskabsteoretiske positioner (Bawden, 2001). Informationskompetence skal forstås på en mange-facetteret måde. Især amerikanske forskere ser koblingen mellem informationskompetence og kritisk tænkning udfra en fokusering på de kognitive processer (Limberg et al., 2002, s. 102), mens andre har mere behavioristiske tilgange gennem formuleringer af mål og standarder for, hvad de studerende skal kunne, og efterfølgende tests af disse, eksempelvis Association of College and Research Libraries's (ACRL) Information Literacy Competency Standards for Higher Education (ACRL, 2000). Dog skal informationskompetence efter min opfattelse ikke begrænse sig til at kunne leve op til disse ydre færdigheder og opfattelser, da informationskompetence også handler om den tilgang man har til informationer i det hele taget. Her har også den sociale og samfundsmæssige sammenhæng informationerne indgår i betydning. Lærernes og bibliotekarernes fælles arbejde med de studerendes informationskompetenceudvikling har betydning for hvad der skal være indholdet i den faglige undervisning på uddannelsesinstitutionerne og i brugerundervisningen på uddannelsesbibliotekerne udfra antagelsen om, at læring og informationssøgning er sammenhængende processer. Informationer og informationssystemer medierer læring. Louise Limberg og Christina Bruce, som er væsentlige forskere på feltet, er enige om at et vigtigt mål for brugerundervisningen fra bibliotekernes og lærernes side er, at de studerende udvikler repertoirer af forskellige måder at forstå information og informationssøgning på. (Bruce, 1997, s. 168; Limberg, 2000, s. 204). Efter inspiration fra Christine Bruce (Bruce, 1997, s.169-170) kan målsætninger for arbejdet med informationskompetenceudvikling beskrives på følgende måde: 
Overordnet målsætning:

- At de studerende kan anvende information effektivt i forskellige kontekster

- At de studerende kan skelne mellem forskellige måder at anvende information på i nye sammenhænge

- At den studerende vurderer information som subjektiv og foranderlig/forandrende

- At den studerende vurderer de sociale dimensioner $\mathrm{i}$ informationer

Operationaliserede mål

- At den studerende er i stand til at anvende konventionel teknologi og informationsteknologi til at indhente informationer

- At den studerende er i stand til finde information, selvstændigt eller via en formidler

- At den studerende kan justere sin informationssøgning efter formålet

- At den studerende kan kontrollere information (korrekte citater og litteraturhenvisninger)

- At den studerende er i stand til at skabe viden på et nyt felt ved at indhente informationer

- At den studerende kan arbejde med viden og personligt perspektiv for at få nye indsigter

- At den studerende kan anvende information klogt til andres bedste

Christina S. Doyle har udvidet den før omtalte definition fra American Library Association, og hun har efter min opfattelse et væsentligt, helhedsorienteret og komplet bud på, hvad informationskompetence er udfra en konstruktivistisk tilgang (Doyle, 1994, s. 34). Hun opfatter informationskompetenceudvikling som en form for kognitiv restrukturering hos den enkelte, dog uden at se disse processer i en social sammenhæng.

Hun fastslår om informationskompetente personer, at disse:

- anerkender at hensigtsmæssig og komplet information er basis for fornuftige beslutninger

- anerkender sine informationsbehov og formulerer spørgsmål på grundlag heraf
- udvikler søgestrategier og identificerer potentielle informationskilder

- skaffer sig adgang til de rette fysiske og digitale informationer

- vurderer og anvender informationer hensigtsmæssigt

- organiserer information for at kunne anvende denne

- har evnen til integrere nye information i sine kognitive strukturer

- kan bruge information til problembehandling og til kritisk tænkning

(Doyle, 1994, s. 30-34)

Elizabeth A. Dupuis ser informationskompetenceudvikling hos de studerende som en $\emptyset$ get kritisk sans og "informationsbevidsthed". Overordnet anser hun informationskompetenceudvikling som en proces der udvikler en persons "informationsbevidshed", således at den enkelte er opmærksom på forskellige relevante informationssystemer, deres opbygning og kompleksitet og evner at udtrykke et informationsbehov, evner at vælge de rette hjælpemidler og kilder. En studerende skal evne at vurdere forskellige former for kilder i forskellige medieformer og evne at bearbejde og vurdere fremfundne informationer på en lødig måde, samt at dokumentere til andre hvor informationerne er fundet, og indholdet af kilderne. (Dupuis, 1997, s. 98)

Som en"checkliste" over de tematikker, som der skal arbejdes med i såvel brugerundervisning som i lærerens og bibliotekarens informationsfaglige vejledning operationaliserer Dupuis informationskompetenceudvikling og informationskompetencetænkningen således:

Informationssystemer - informationskilder:

- Den studerende har kendskab til former for informationssystemer indenfor det faglige felt

- Den studerende har forståelse for de forskellige former for teknologier der er anvendes i systemerne

- Den studerende kan anvende computere og anden teknologi til opfyldelse af informationsbehov 
- Den studerende har forståelse for at alt relevant information ikke kan findes på en $\mathrm{pc}-\mathrm{og}$ på nettet

- Den studerende har forståelse for de forskellige publikationsmåder, der findes

- Den studerende har forståelse for at informationssøgning tager tid, og at dens succes er afhængig af ens viden

- Den studerende har forståelse for ophavsrettigheder, og for den rette dokumentation af anvendt information

- Den studerende kan anvende forskellige former for informationskilder

\section{Adgang og udvaelgelse af informationssystemer}

- Den studerende kan skaffe sig virtuel adgang til relevante informationssystemer (databaser, netsteder - cd-roms og forskellige former for fuldtekstkilder).

- Den studerende kan anvende forskellige former for søgeteknikker til fremskaffelse af informationer

- Den studerende kan udføre søgning udfra søgestrategier - og kende forskel på præcise og udforskende søgninger, og har kendskab anvendelse af kontrollerede søgninger (kontrollerede emneord)

\section{Vurdering af informationer}

- Den studerende evner kritisk anvendelse af kilder (ophav, publikationsmåder, former for information)

- Den studerende anerkender vigtigheden af informationskilders autoritet, lødighed, synspunkter og grundlæggende antagelser.

\section{Organisering af information}

- Den studerende evner at citere anvendte kilder korrekt - og lødigt dokumentere anvendelse af kilder.

- Den studerende kan udføre downloads og læse internetdokumenter via Acrobat-Reader

- Den studerende er i stand til fysisk/virtuelt at anskaffe sig den $\emptyset$ nskede information blandt andet udfra tidsmæssige og kvalitetsmæssige kriterier

- Den studerende kan formidle information via PowerPoint, web og cd-rom.
Informationskompetenceniveauer kan efter min opfattelse ikke "måles" præcist og nøjagtigt, men informationskompetencetænkning kan medvirke til forståelse af den enkeltes mestring af sit informationsmiljø. Et eksempel kan være de overvejelser den studerende bør gøre sig omkring sine søgestrategier i forbindelse med forskellige former for unders $\emptyset$ gelsesarbejder. Informationskompetence skal således ikke forstås kun som kognitive færdigheder, idet den enkelte studerende både skal kunne forholde sig til information intellektuelt og socialt: "intellectual grasp of information sources". Fokus på informationskompetenceudvikling skal medvirke til at sikre at de studerende får en "bred" forståelse af alle former for informationsressourcer og informationssystemer. I de forskellige studier af informationskompetenceudvikling ser jeg en tæt sammenhæng mellem informationssøgning og informationsanvendelse i forbindelse med studiearbejdet, og jeg opfatter informationskompetence som en kritisk forholden sig til anvendelse af informationer. I et sammenfattende notat fra 2002 om informationskompetenceudvikling fra ERIC Clearinghouse hedder det:

"There is a clear need for discussion of information literacy instruction outside of the library field. A more multi-disciplinary approach to information literacy research and instruction will create opportunities for more substantial, curriculum-integrated and long-lasting instructional experiences that will benefit students throughout and beyond their academic careers."

(Kasowitz-Scheer \& Pasqualoni, 2002)

Det er min opfattelse at lærerne implicit og eksplicit må inddrage udvikling af informationskompetencer i deres tilrettelæggelse af såvel undervisning som vejledning. Bibliotekarer må i deres brugerundervisning og i den daglige vejledning i biblioteket have informationskompetenceudvikling som omdrejningspunkt og grundlæggende antagelse. Desuden må hver enkelt uddannelsesinstitution udvikle en fælles forståelse af informationskompetencer, idet en sådan skal være grundlaget for arbejdet med udviklingen af de studerendes studiemetodiske 
færdigheder. I øjeblikket arbejder vi på Viborgseminariet med følgende forståelse af begrebet, og lærergruppen debatterer i øjeblikket udvikling af de pædagogstuderendes studiemetodiske færdighed med informationskompetencetænkning som et af omdrejningspunkterne.

\section{Viborg-seminariets forståelse af informations- kompetenceudvikling}

På Viborg-seminariet arbejder vi i CVU MidtVest's informationskompetenceudviklingsprojekt, som omtales senere, med informationskompetenceudvikling som en del af en stadig fremadskridende studiemetodisk udviklingsproces for den enkelte studerende i pædagoguddannelsen. Denne progression i informationskompetenceudvikling ser vi som en proces, hvor der først arbejdes på at kende - dernæst på at kunne og til sidst på at beherske niveauer omkring indsamling, bearbejdning og anvendelse/re eksion over faglige tekster. På Viborg-seminariet forstås information, som fortrinsvis forskellige faglige tekster i forskellige formater, for netop at imødekomme det pædagogiske personales opfattelse af information, idet disse f.eks. ikke klart skelner mellem data, information og viden. De studerendes informationshåndtering opfattes eksplicit som en del af deres almene studiemetodiske færdigheder. Det er vigtigt at anvende det pædagogiske vokabularium også når der diskuteres informationskompetenceudvikling.

Informationskompetence forstår vi på Viborg-seminariet som evnen til at: finde faglige tekster, evnen til re ektere og anvende faglige tekster, og evnen til at kommunikere og præsentere faglige tekster:

Den informationskompetente pædagogstuderende er således opmærksom på: hvornår der er brug for faglige tekster, hvordan faglige tekster er organiseret i forskellige informationssystemer og hvordan faglige tekster optræder i forskellige medieformer (fysisk-elektronisk) og hvordan han/hun finder, re ekterer, evaluerer og kommunikerer faglige tekster.
Den informationskompetente studerende bestemmer brugbarhed af faglige tekster, skelner mellem synspunkter og fagligt/videnskabelig begrundede opfattelser, identificerer unøjagtige og misvisende faglige tekster og udvælger passende faglige tekster på relevant niveau til den aktuelle problemstilling i sit studiearbejde.

\section{Informationskompetenceudviklings projekt på CVU MidtVest 2003-2004}

Informationskompetenceudviklingsprojektet er støttet af Undervisningsministeriets erårsaftalemidler (4/5) og af Bibliotekarforbundets udviklingsfond (1/5) med deltagelse af 5 bibliotekarer og 6 lærere fra 5 forskellige uddannelsesinstitutioner. Flerårsaftalemidlerne har til formål at $\emptyset$ ge kvaliteten af de enkelte seminariers undervisning og har desuden til formål at udvikle projektdeltagernes kompetencer og øge samarbejdet i CVU-regi. I projektet afsættes ressourcer (120 timer/pr. person) til et tværfagligt samarbejde, hvor lærere og bibliotekarer i små arbejdsgrupper med deres forskellige fagligheder sammentænker og udfører undervisning og brugerundervisning (informationssøgningsundervisning) i sammenhæng med den enkelte institutions studieordning og læseplaner for studieforløb og fag. Visionen med et fælles udviklingprojekt i CVU MidtVest med start i januar 2003 er, at de studerende i uddannelserne opnår en erkendelse af hvordan og hvorfor de skal have kendskab til relevante informationssystemer og - kilder, og at de opnår kompetencer i informationssøgning til studieformål. Visionen er også at fremme informationskompetencetænkningen gennem udvikling et "fælles" sprog om informationskompetencer på de deltagende seminarier, idet det fælles mål for lærere og bibliotekarer er at skærpe de studerendes kritiske sans i studiearbejdet og dermed at udvikle deres studiemetoder.

Denne bestræbelse er som tidligere nævnt tydeliggjort af professionsbacheloruddannelsernes krav om udvikling af de studerendes færdigheder i og forudsætning for at indsamle, bearbejde og anvende relevant information indenfor det pædagogiske område. 
Desuden skal dette CVU-projekt diskutere informationskompetencebegrebet, og et væsentligt mål er at lærere, ledelse og biblioteksansatte på det enkelte seminarium har en fælles forståelse af informationskompetence og informationskompetence-udvikling. Informationskompetenceudvikling skal i projektets forståelse være et fælles anliggende for ledelser, lærere, bibliotekarer og pædagogiske IT-vejledere, og kun et godt samarbejde mellem disse grupper kan sikre optimale studiemiljøer på uddannelsesinstitutionerne $\mathrm{i}$ en tid, hvor omlægning af studieformer betyder større selvstændighed i læringsarbejdet for de studerende. Udvikling af fælles planlægning af undervisningsforl $\varnothing b$ er en vigtig del af projektet. Her vil forskellige fagligheder komme i spil til gavn for informationskompetenceudviklingen. Vi er i projektet $\mathrm{i}$ fuld gang med at finde de uddannelsesforl $\varnothing \mathrm{b}$ og fag i såvel pædagog- som i læreruddannelsen, hvor dette kan foregå mest hensigtsmæssigt, og vi forsøger at få informationskompetencer med som et væsentligt mål i de lokale studieordninger og læseplaner.

I pædagoguddannelsen findes der projektforløb, hvor der kan arbejdes med informationskompetenceudvikling i tæt sammenhæng med undervisningen. Vi arbejder med fælles undervisningstilrettelæggelse i forhold til de forskellige projekter i pædagoguddannelsen, hvor det er oplagt at arbejde med udvikling af de studerendes informationskompetencer. Desuden findes der et socialfagligt forløb, hvor der kan arbejdes med juridisk informationssøgning i form af opgaver og cases. Her er fællesundervisning af bibliotekar og lærer oplagt og allerede afprøvet i forbindelse med projektet.

I læreruddannelsen kan der i forbindelse med studieforløbet "Skolen i samfundet" og i liniefag undervises i fagenes forskellige informationskilder, artikelbaser, cd-rom og online opslagsværker, samt i hvor relevante internetudgivelser kan findes. De studerende tilbydes f.eks. en introduktion til "problembaseret" informationssøgning med udgangspunkt i egne problemformuleringer og ved a evering kan de skriftlige søgestrategier/litteraturlister danne grund- lag for en opsamling. Der arbejdes endvidere med at de studerende $\mathrm{i}$ forbindelse med forskellige opgaveforl $\varnothing \mathrm{b}$ skriftligt skal gøre rede for søgestrategier i forhold til den valgte litteratur, og at dette kommer til at indgå i bedømmelsen af opgaven. Udviklingen af de studerendes informationskompetencer bør foregå mange steder i uddannelsesforløbene med tydelig progression og i nær tilknytning og sammenhæng til fagene og studieforl $\varnothing b$. Vi arbejder i projektet med at informationskompetenceudvikling skal ske $\mathrm{i}$ forbindelse med de konkrete selvstændige opgaver, som de studerende står over for, herunder bl.a. praktikperioder, studieopgaver og bacheloropgaver.

For uddannelsesbibliotekernes vedkommende er vi i projektet kommet til den erkendelse, at der ikke kun skal arbejdes med de studerendes informationskompetenceudvikling i brugerundervisningen, men især i den daglige vejledning til brugerne. Der vil endvidere være organisatoriske, ressourcemæssige og fysiske rammer, der skal ændres for at støtte denne udvikling. Bibliotekerne og lærerne skal afsætte de nødvendige tidsmæssige ressourcer til dette arbejde i en tid, hvor der opleves stor mangel på undervisningstid og på tid til biblioteksarbejde. Samtidig skal de fysiske og organisatoriske rammer ofte ændres for at denne udvikling kan lykkes. Et vigtigt indsatsområde vil sikkert også blive lærernes egen informationskompetenceudvikling, og udvikling af bibliotekspersonalets pædagogiske kompetencer.

I såvel grunduddannelserne som PD-uddannelserne på CVU MidtVest's partnerinstitutioner (2 pædagogseminarier, 3 lærerseminarier) udgør søgning efter supplerende materialer (bøger, avis- og tidsskriftsartikler) og andre informationer f.eks. på internettet en vigtig del af studiearbejdet. I vores kontekst er erhvervelse af et godt indblik i informationssøgeprocesser og af informationskompetencer derfor et vigtigt element i den læring og vejledning, der foregår på uddannelserne. Vi ser i vores projekt, at lærernes/vejledernes anbefalinger af litteratur og andet relevant materiale er særdeles vigtig. En anden ting er at de biblioteksansatte bør tilbyde undervisning og vejledning i mere systematisk litteratursøg- 
ning ved de studerendes større studieopgaver og bachelor-projekter. Informationss $\varnothing$ gearbejde, som bl.a. foregår i partnerinstitutionernes biblioteker, $\mathrm{i}$ andre biblioteker, på institutioner, på internettet og ved personlig kontakter skal ses som sammenhørende med faserne i det $\emptyset$ vrige projektarbejde. Brugerundervisning og biblioteksvejledning i informationssøgning skal således understøtte læreprocesserne i $\varnothing$ vrigt på uddannelsesinstitutionerne.

Via fokusering på informationskompetenceudvikling i CVU MidtVest er det et mål, at der sker en styrkelse af de studerendes studiemetodiske færdigheder. Det er således vigtigt at sikre en øget forståelse for sammenhængen mellem informationss $\varnothing g$ ning og læring på alle partnerinstitutionerne blandt lærere og bibliotekarer. Uddannelsesbibliotekernes virksomhed skal fremover først og fremmest ses som pædagogisk støttefunktion - ikke kun som en service- og materialeforvaltende funktion.

Det er et håb i dette projekt at kunne eksplicitere bibliotekarernes rolle i forbindelse med uddannelserne, især når de studerende laver projektarbejder og større opgaver. Bibliotekspersonalets funktion udvikler sig hen imod en proaktiv, rådgivende og intervenerende rolle i informationssøge- og læringsprocesser. Et andet vigtigt mål i projektet er at kunne udvikle samarbejdet mellem lærere og bibliotekarer på den enkelte partnerinstitution gennem fælles informationskompetencetænkning i forhold til studieordninger og de enkelte studieforløbs og fags læseplaner. Bibliotekarerne kan i deres brugerundervisning og i deres vejledning til de studerende i langt højere grad tænke læring/pædagogik - og lærerne kan i deres undervisning i langt højere medtænke informationskompetenceudvikling i det enkelte fag eller projekt- og studieforløb.

Underviserne har i kraft af deres kendskab til fagene, samt kendskab til læreprocesser den væsentligste rolle, men denne rolle forandres også hen imod en mere vejledende og læringsinitierende rolle, hvor lærernes egne informationskompetencer også skal videreudvikles. Med informationskompetencebe- grebet som "optik" vil lærerne i deres vejledning af de studerende i forskellige studieforløb få et værkt $\varnothing j$, der kan udvikle og kvalificere vejledning af de studerende. Bibliotekarerne kan udfra et overordnet kendskab til emneområder vejlede i og give adgang til grundlæggende, relevante og aktuelle informationer i materialer hos personer og organisationer og i databaser. Desuden har bibliotekarer kvalifikationer i at afdække informationsbehov og i at "oversætte" disse til søgetermer i f.eks. biblioteksdatabaserne. Bibliotekarernes viden om søgemetoder kan medvirke til at forbedre og sikre bedre relevansvurderinger og analyser af de studerendes informations $\emptyset$ gninger.

I forhold til facilitering af de studerendes læreprocesser giver projektet mulighed for, at bibliotekarernes og lærernes forskellige fagligheder i højere grad spiller sammen. Underviserens felt og bibliotekarernes faglige felter skal i projektet mødes på nye måder. Bibliotekarerne skal gennem projektet erhverve en større erkendelse af, hvordan biblioteksfunktionen mest optimalt bidrager/underst $\varnothing$ tter de studerendes læring. Underviseren må vide noget om hvilke informationsressourcer og -systemer der findes, og hvordan informationsressourcerne udnyttes på en optimal måde i læringssituationer i undervisningen, bl.a. i vejledningssituationer.

\section{Projektstyring via SMTTE-modellen}

I vort informationskompetenceprojekt pågår der en lidt utraditionel projektudvikling. Traditionel og målrettet projekttænkning, hvor målene for projekterne defineres så nøjagtigt som muligt, og hvor indsatsen planlægges, gennemføres og evalueres udfra de opstillede mål i form af en målrationel projekttænkning er blevet udsat for kritik. Kritikken går på at man reelt afskærer sig fra at udnytte den læring og udvikling projektdeltagerne opnår, mens projektet gennemføres. Projektformål fastsættes eksempelvis ofte når deltagernes viden er mindst. Det er især Christensen og Kreiner (1994) som peger på dette fundamentale problem. Projektdeltagerne får som regel henover projektforløbet større viden af relevans for projektet, også i kraft af at man har 
fået tilført tidsmæssige ressourcer til projektet. Udfordringen i vores projekt ligger i, at vi skal finde en arbejdsform, hvor vi eksperimenterer og udforsker, samtidig med at projektet udvikler sig målrettet og systematisk. Det handler om at planlægge en læreproces og ikke kun konkrete tidsfastsatte aktiviteter. I målsætningsfasen er det således vigtigt, at man ikke definerer for præcise og målbare mål, men at man derimod arbejder med visioner, som man kan samles om. Endvidere skal man tage hensyn til den kontekstuelle usikkerhed, der ligger i at omverdenen hele tiden udvikler sig og stiller nye krav. De krav som omverdenen stillede, da projektet gik i gang er måske ændrede. Aktuelle nedskæringer, ændringer i uddannelserne og organisationsændringer kan eksempelvis have stor ind ydelse på arbejdet. Desuden ligger der jo den processuelle usikkerhed ved at anvende helt klare planer og styringsredskaber, og der vil også være problemer med hvordan de nye erkendelser implementeres i organisationens drift. Vi har oplevet at informationskompetencetænkningen har kunnet bidrage til lærernes vurdering af projekter og bacheloropgaver, idet vi i projektet har analyseret studerendes specialer for "tegn" på de studerendes informationskompetencer og dermed deres studiemetodiske niveau.

Vi anvender SMTTE- tænkningen (Boye Andersen, 2000), en simpel udviklings-, evaluerings- og kvalitetssikringsmetode, som er et opg $\varnothing \mathrm{r}$ med den målrationelle projekttænkning, hvor for præcise opsatte mål kan blive en barriere fordi det kan betyde en for "hæmmet" tænkning og udvikling i projektet, der har med mennesker og menneskelige processer at gøre. Bogstaverne SMTTE står for Sammenhaeng, Mål, Tiltag, Tegn og Evaluering. Det er en dynamisk relationel model (se figur) i form af, at de enkelte processer og dele af forløbet ikke skal gennemføres i en bestemt rækkefølge eller efter et bestemt system. Måden at arbejde på tvinger projektdeltagerne til at tænke konkret og i beskrivende termer, frem for i mere overordnede begreber i informationskompetenceudviklingen. Det er ikke nok at formulere, at man vil fremme informationskompetencetænkningen for at udvikle de studerendes studiemetoder.
Det er vigtigt konkret at lave forskellige tiltag og indsatser for dette, og at projektdeltagerne finder ud af hvilke tegn, der kan vise om informationskompetencetænkning fremmer de studerende studiemetodiske kompetencer.

Tiltagene i projektet er de aktiviteter der foregår i eksempelvis vort fælles arbejdsgruppearbejde mellem lærere og bibliotekarer, fælles workshops hvor der arbejdes med informationskompetenceudvikling, med udarbejdelse af skriftlige definitioner på informationskompetencer, med fælles diskussion og tilrettelæggelse af bibliotekernes brugerundervisning og med forslag til studieordninger, deltagelse $\mathrm{i}$ lærermøder, udvalg og konferencer, hvor informationskompetenceudvikling er på dagsordenen.

Søgningen efter tegn er særdeles vigtig i denne projekttænkning. Tegn er konkrete identificerbare forhold, som peger på at en projektudvikling går i den "rigtige" retning, og som er medvirkende til at håndtere omsætningen fra mål-niveau til handle-niveau. Tegn er konkretiseringer og repræsentationer for målene, og er udtrykt i "praksistermer". Bestemmelse af tegn gennem drøftelse og samtale i projektgruppen betyder ifølge SMTTE-tænkningen også en bevægelse hen imod disse tegn. Tegnene operationaliserer og differentierer målene. I den forbindelse søger vi i vort projekt efter tegn på informationskompetencer i de studerendes studieopgaver og projekter f.eks. i form af god dokumentation og anvendelse af relevant og nyere litteratur. Vi søger efter tegn på, at lærerne og bibliotekspersonalet har medtænkt informationskompetenceudvikling i deres informationsfaglige vejledning og gennem samarbejdet om læseplaner og studieforl $\emptyset \mathrm{b}$, gennem en fælles lærer- og bibliotekarvurdering af, om de studerendes har anvendt de "rette" faglige tekster på rette niveau, om der er citeret korrekt, og om litteratursøgningen har været god nok. Er der overset centrale tekster og nyere undersøgelser? Desuden kan tegn være nye organisationsformer på institutionen $\mathrm{i}$ form af etablering af læringsressourcecenter, og tegn kan være en ændring af bibliotekernes brugerundervisning, så den planlægge og koordineres bedre med 
den $\varnothing$ vrige undervisning.

Sammenhang er i dette tilfælde det aktuelle informationskompetenceprojektets samfundsmæssige, politiske, pædagogiske, værdimæssige og biblioteksfaglige kontekst. Alle udviklingsprocesser er funderet i en virkelighed, som sætter nogle "rammer", og som har ind ydelse på udviklingsprocessen. Det er i dette tilfælde den samfundsmæssige og uddannelsespolitiske udvikling i retning af øgede teoretiske kundskaber i professionsuddannelserne, $\emptyset$ get livslang kompetenceudvikling, reduceret formidlende undervisning, den pædagogiske udvikling i retning af øget egenaktivitet og ansvar for egen læring. Endvidere slår informationskompetencetænkningen igennem i det biblioteksfaglige tænkning i uddannelsesverdenen. Målene og visionerne, der sættes op er overvejelser over informationskompetenceprojektets bestræbelse på at udvikle informationskompetencetænkningen på den enkelte uddannelsesinstitution.
Endelig rummer evaluering en status over hvad der er set og hørt, en vurdering af dette og heraf følgende ideer til næste skridt i udviklingen. Dette vil vi gøre gennem samtaler med nøglepersoner og fokusinterviews af forskellige grupper. Evaluering skal ikke kun foretages til sidst, men også i selve projektprocessen, og den skal give ideer til næste skridt. Kan studieledelser og studerende give ideer til projektet? Hele SMTTE-processen rummer mulighed for en udviklende evaluering, idet der løbende arbejdes med mål, tiltag og tegn.

I øjeblikket (maj 2003) ser vor relationelle SMTTEmodel således ud, og der er ingen tvivl om at vi får nye tegn og tiltag længere fremme i projektet hvor vi alle er klogere, såvel de 6 deltagende lærere som de deltagende bibliotekarer. Det er jo det det handler om - at vi sammen bliver klogere på informationskompetenceudvikling til gavn for vore studerende. 
CVU-MidtVest sætter fokus på de studerendes informationskompetence-udvikling som en del af de studerendes udvikling af studiemetoder i forhold til kravene til professionsbachelor. Informationskompetenceudvikling er et fælles anliggende for lærere og bibliotekarer. Bibliotekerne har en pædagogisk støttefunktion i forhold til uddannelserne - ikke kun servicefunktion. Informationskompetencer er et relevant pædagogisk begreb.

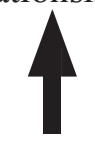

\section{Sammenhæng}

Forståelse af informationskompetencebegrebet. Workshops. Lærer-bibliotekar grupper nedsat på seminarierne. Integrere tænkning i fag og i brugerundervisning. Udarbejde plan for implementering. Gennemføre fælles planlagte forløb. Formidling til bibliotekarfora + lærerfora

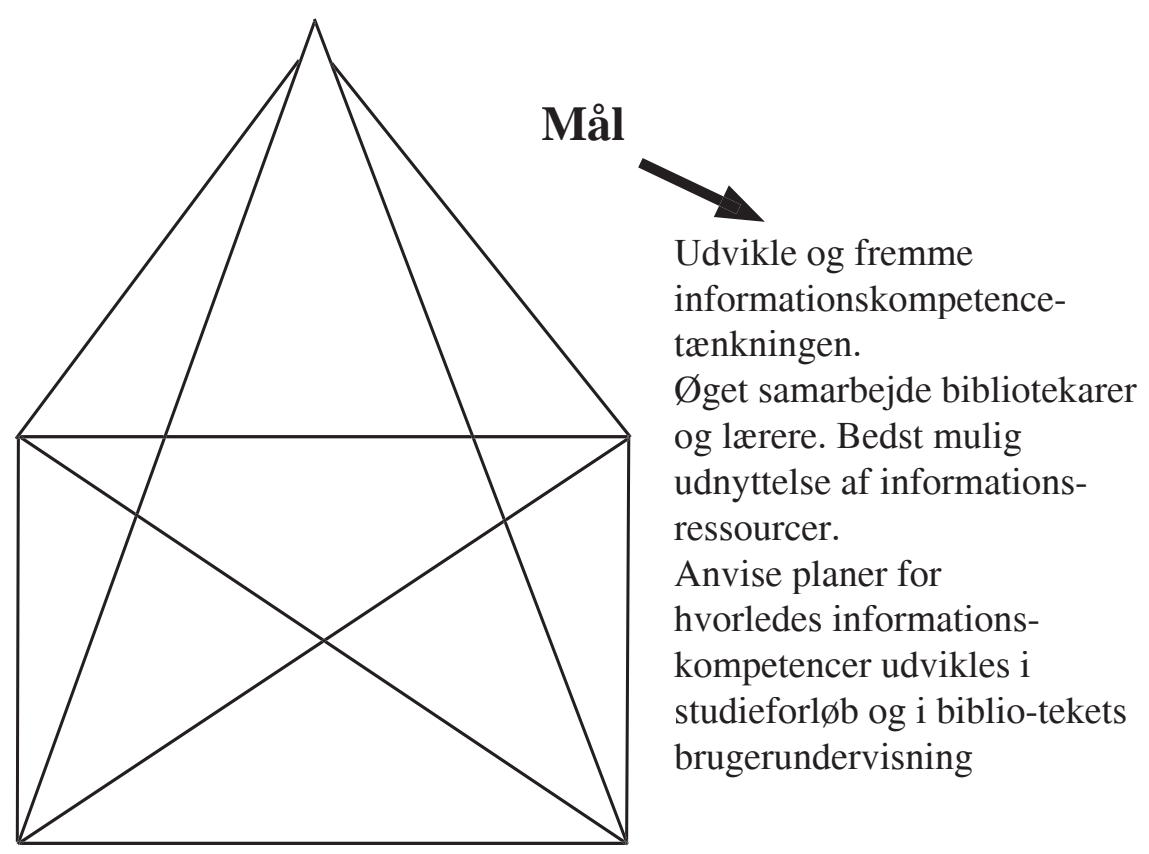

\section{Evaluering}

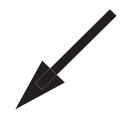

Interview-samtale studieledere Interview med lærere + studerende om læring og informationssøgning Interview (fokusgruppeinterview) med bibliotekspersonale om bibliotekets undervisning og vejledning i informationssøgning

\section{Tegn}

Informationskompetencer i studerendes skriftlige arbejder. Spørgsmål fra de studerende om dokumentation af kilder Oplæg til lærere med anvendelse af informationskom petencetænkning i f.eks. vurdering af bacheloropgaver - studieopgaver.

Informationskompetenceudvikling nævnt i studieordninger og læseplaner.

Fælles planlægning af arbejdet med informationskompeten ceudvikling.

Udviklede og gennemførte forl $\varnothing b$ i studieforl $\varnothing b$ og projekter og bibliotekets brugerundervisning med udvikling af informationskompetencer.

Informationskompetenceudvikling indgår i organisationsplan 


\section{Litteratur:}

ALA (1989). American Library Association Presidential Committee on Information Literacy: Final report. Chicago : ALA. Lokaliseret den 12. august 2003 på World Wide Web: http://www.infolit.org/ documents/89Report.htm

Bawden, D. (2001). Information and digital literacies: A review of concepts. Journal of Documentation, 57(2), $218-259$

Bekendtgфrelse om andring af bekendtg $\phi$ relse om uddannelse af padagoger. BEK nr 706 af 23/07/ 2001.

Boye Andersen, F. (2000). Tegn er noget vi bestemmer: Evaluering, kvalitet og udvikling i omegnen af SMTTE-tankningen. Århus : Danmarks Lærerhøjskole

Breivik, P.S. (1998). Student learning in the information age. Phoenix : American Council on Education/Oryx Press

Bruce, C. (1997). The seven faces of information literacy. Adelaide : Auslib Press

Christensen, S., \& Kreiner, K. (1994). Projektledelse $i$ løst koblede systemer: Ledelse og laring $i$ en ufuldkommen verden. København: Jurist- og $\varnothing$ konomforbundet

Doyle, C.S. (1994). Information literacy in an information society: A concept for the information age. Syracuse, NY : ERIC Clearing House on Information and Technology

Dupuis, E.A. (1997). The information literacy challenge: Addressing the changing needs of our students through our programmes. Internet Reference Services Quarterly, 2(2/3), 93-112

Hermann, S. (2003). Fra styring til ledelse: Om kompetencebegrebets udvikling. Uddannelse, 36(1), 3 - 14
Hygum, E., Gytz Olesen, S., \& Møller Petersen, P. (2003). Bachelorbekendgørelsen som udviklingsprojekt. I: L. Ærø (Red.), Padagogen som professionsbachelor (s. 56 - 71). Viborg : PUC

ACRL (2000). Information l iteracy competency standards for higher education. Lokaliseret den 6. juni 2003 på World Wide Web: http://www.ala.org/ Content/NavigationMenu/ACRL/Standards and Guidelines/Information_Literacy_Competency Standards_for_Higher_Education.htm

Limberg, L., Hultgren, F., \& Jarneving, B. (2002). Informationssökning och lärande: En forskningsöversikt. Stockholm : Skolverket Tilgængelig på World Wide Web: http://www2.skolverket.se/ BASIS/skolbok/webext/trycksak/DDD/935.pdf

Kasowitz-Scheer, A., \& Pasqualoni, M. (2002). Information literacy instruction in higher education: Trends and issues. ERIC Digest, EDO-IR-2002-01. Lokaliseret den 12.august 2003 på World Wide Web. http://www.ericit.org/digests/EDO-IR-200201.shtml

NKR (2002). Nøglekompetencer: Forskerbidrag til Det Nationale Kompetenceregnskab: Dokumentationsrapport. København : Undervisningsministeriet. Tilgængelig på World Wide Web: http: //pub.uvm.dk/2002/nkr/dokumentationsrapport/ dokumentationsrapport.pdf

Pilegaard Jensen, T. (2002). Literacy-kompetence. I : Nøglekompetencer: Forskerbidrag til Det Nationale Kompetenceregnskab: Dokumentationsrapport (s. 21-39). København : Undervisningsministeriet.

Tilgængelig på World Wide Web: http:// www.nkr.dk/db/filarkiv/4137/Literacy.doc

Spitzer, K.L., Eisenberg, M.B., \& Lowe, C.A. (1998). Information literacy: Essential skills for the information age. IR-104. Syracuse, N.Y. : ERIC Clearinghouse on Information and Technology, Syracuse University 
Undervisningsministeriet (2002). Professionsbachelor-uddannelsen: Katalog over kriterier 2001. Lokaliseret den 12. august 2003 på World Wide Web: http://www.nkr.dk/db/filarkiv/4137/ Literacy.doc 